\title{
'A HOARY ANTIQUITY OF UNIMAGINED REMOTENESS': \\ A Historiography of Archaeological Investigations at the Cheddar Gorge, Somerset, UK.
}

Katie Davenport-Mackey ${ }^{1} \&$ Paul R Preston ${ }^{2}$

${ }^{1}$ School of Archaeology and Ancient History

${ }^{2}$ Lithoscapes Archaeological Research Foundation University of Leicester

Rose House

University Road

Mellguards

Leicester,

LE1 7RH

Southwaite

Carlisle

CA40LE

UK.

UK.

Corresponding Author: paul@lithoscapes.co.uk

\begin{abstract}
For the most part, histories of the archaeological discoveries in Cheddar Gorge have been based on anecdotal or oral accounts. Such evidence is unreliable and if accepted uncritically may result in the spreading of inaccurate information and the perpetuation of myths that distort our knowledge of the past and ultimately obfuscate future research. Indeed, most histories of the investigations at Cheddar Gorge have been simple uncritical narratives that fail to evaluate the veracity of sources of information as well as the quality of the archaeological information obtained. Therefore, to verify the claims of archaeological discoveries in Cheddar Gorge, the aims of this paper are to undertake a historiographical analysis of archaeological studies and excavation reports and to undertake a resource assessment of the actual archaeology recovered and recorded. This paper, therefore, not only demonstrates that historical documents can provide archaeologically relevant information about past investigations at Cheddar Gorge, but also outlines a more relevant, verifiable, and unbiased history for use by current and future researchers.
\end{abstract}

Keywords: Palaeolithic, Mesolithic, Neolithic, Bronze Age, Historiography, Archaeological Resource Cheddar Gorge. 


\section{INTRODUCTION}

Prehistoric archaeology is often thought to represent an alien way of life which has left only meagre archaeological traces (Smith, 1992: 106). It is therefore of no surprise that Herbert Ernest Balch (1935: 106) described the archaeology of Cheddar Gorge in mythical prose as epitomising 'a hoary antiquity of unimagined remoteness' in the first attempt at a synthesis of the archaeological work in the caves of the gorge. His account takes a biographical and anecdotal approach to history based on personal reminiscence and eyewitness memory and seems to have unintentionally established the approach employed in ensuing syntheses (e.g. inter alia Branigan and Dearne, 1991; Bryant, 2011; Lewis, 2005). This approach, however, is characterised by an acceptance of anecdotes and testimonials with little critical evaluation.

However, such an anecdotal approach impedes research due to two main reasons. First, researchers often fail to appreciate the potential difference in accuracy between primary and secondary sources. For example, primary sources ${ }^{1}$ may be fraught with inaccuracies and distortions (Buckhout, 1975; Clifford and Scott, 1978; Loftus, 1979; Wells and Olson, 2003) and secondary sources ${ }^{2}$ are only as reliable as the good as the sources used and the level of critique employed. That is writers who take this approach often take the anecdotes and re-report them without any assessment. Secondly, researcher's interpretations are often based on the perceived expertise of an archaeologist. These 'arguments from authority' or 'appeals to authority' tend to lack supporting data. Consequently, this hampers the reader's ability to evaluate the original data and to test whether the arguments are valid. Hence, the value of the archaeological research resource cannot be assessed.

Therefore, this paper takes three different approaches towards a more objectively verifiable history of the archaeological discoveries in Cheddar Gorge. Firstly, the paper focuses primarily on the prehistoric archaeology of Cheddar Gorge. Secondly, for brevity, it concentrates on the primary interventions at the Cheddar Caves. Thirdly, the paper synthesises the sources into a narrative capable of withstanding scrutiny through a historiographical approach (sensu Fling, 1899; Fling and Theodore, 1920; Vann, 2015) based on a critical analysis of the reliability of sources (both documentary or physical). Therefore, the authors will review the archaeological

\footnotetext{
${ }^{1}$ Primary sources in this case are the original archaeological reports, field notes, or eyewitness testimonies.

${ }^{2}$ Secondary sources in this case ate the historical accounts written by the archaeologist's.
} 
investigations at Cheddar Gorge and audit of the archaeological resource ${ }^{3}$ at Cheddar Gorge by bringing together information from a range of published sources in a critical synthesis.

Before considering the historiography of and archaeological resources at each prehistoric site/occupation from the gorge, the impact of the geography of the Cheddar Gorge is assessed. Next the paper considers the overall effect of the archaeological studies in the area as well as the value of the information and evidence for future research. Thus, before proceeding with the historiography, it is necessary to describe briefly and appreciate the context of the research area.

\section{THE GEOGRAPHY AND GEOLOGY OF CHEDDAR GORGE}

For the most part, previous syntheses of the history of archaeological investigations in the Cheddar Gorge have failed to appreciate the influence of the geographical and geological context has on human activity and occupation. This omission misses three fundamental issues regarding human occupation in Cheddar Gorge and the history of the archaeological work in the gorge. First, human activity occurs within a physical, biological, and cultural landscape (Conneller, 2007; Tilley, 1994). Secondly, this landscape enables and constrains human action. Thirdly, the geology, topography, and geomorphology of the landscape influence the survival and recovery of archaeological material (Schiffer, 1987). Therefore, any history of the discoveries in Cheddar Gorge is necessarily incomplete without—at the very least- a consideration of the geographic and geologic context of the gorge. It would be possible to write an entire paper on the geography and geology of Cheddar Gorge but such an undertaking is beyond the scope of this paper, however, which will instead briefly summarise the key physical features.

A dominant topographic feature of the Somerset landscape is the Mendip Hills (Figures 1A \& B). The Mendip Hills are a Carboniferous Limestone plateau running diagonally north-west to south-west across Somerset and rising to an average height of $240 \mathrm{~m}$ above OD (Green and Welch, 1965: 1). The Mendips also represent an important watershed for rivers that flow underground due to the permeable limestone to emerge as springs, risings, and resurgences at the foot of the hills (Green and Welch, 1965: 2). Indeed, the continual percolation of water -

\footnotetext{
${ }^{3}$ An archaeological research resource is defined to the material remains of past human activities which are of archaeological interest, as opposed to cultural or legal significance (see in Carver, 1996; Darvill, 1994; Glassow, 1977; Hunter and Ralston, 2006; Willems, 2008).
} 


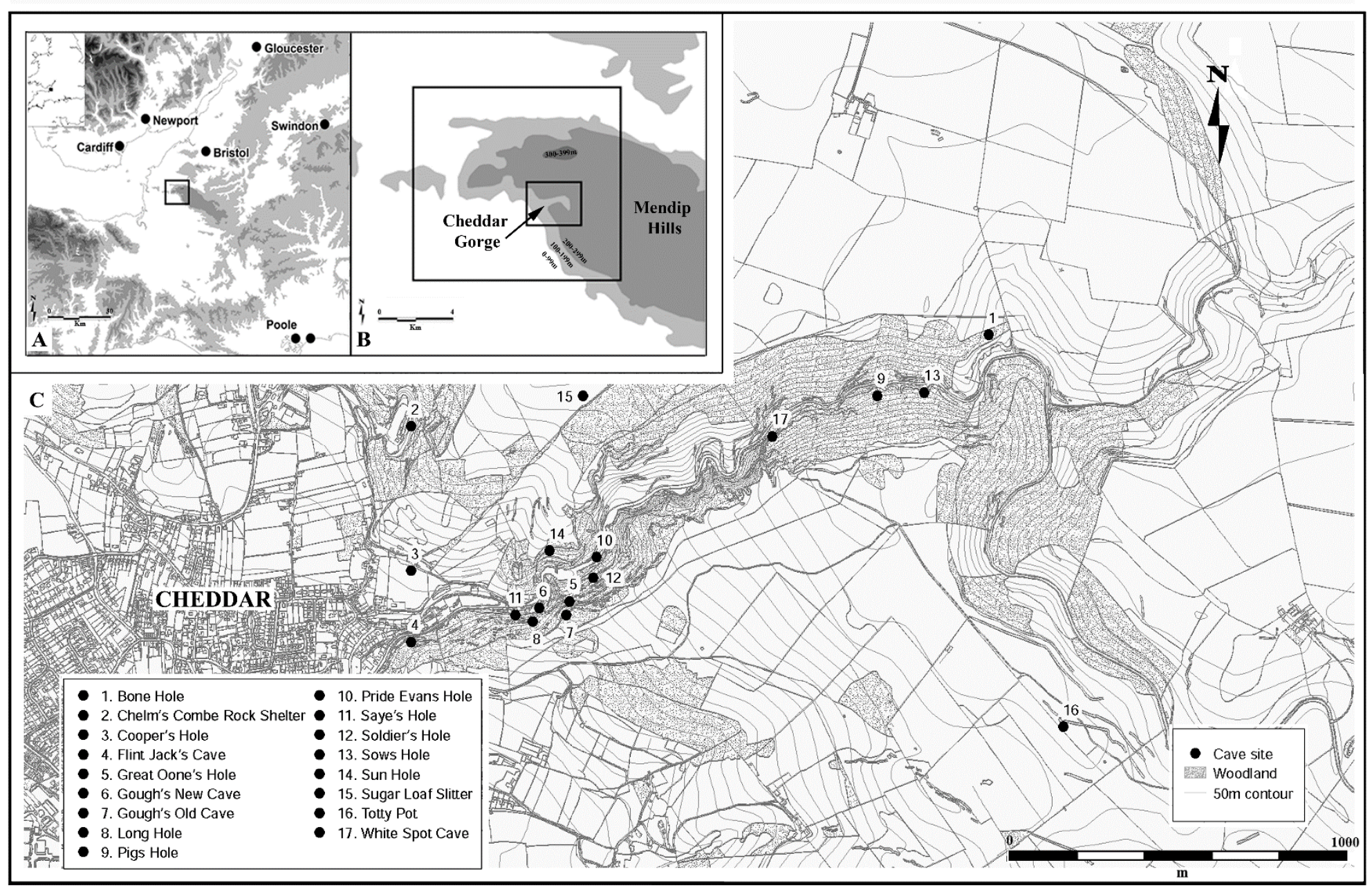

Figure 1. Situation of the Prehistoric sites in The Cheddar Gorge

Prepared by P R Preston, with Figure 1C based on data a GIS base map by Mary Saunders, and site data in Davenport-Mackey (in prep) and OS map Data (C Crown Copyright and Database Right 2016. Ordnance Survey [Digimap Licence]). 
through the limestone is responsible for the formation of the karstic topography of cliffs, gorges, combes, and caves which characterise Somerset (Green, 1992: 7).

A characteristic feature of the karstic topography of the Mendip Hills are the numerous shallow dry valleys that descend into steep-sided gorges and combes. For example, the Cheddar Gorge, Ebbor Gorge, and Burrington Combe (Green and Welch, 1965: 124). The largest of these is Cheddar Gorge, which extends $2 \mathrm{~km}$ east-west from the village of Cheddar (Waltham et al., 1997: 193). Cheddar Gorge has exerted an influence on human affairs, from the occupation in the Stone Age to the archaeological discoveries of the nineteenth century onwards.

The Karstic topography of the gorge has had an impact on both the human activity because it is is an ecotone between the upland and lowland habitats that offers a number honeypot features making it attractive for human occupation. For example, it provides an easy transit route (sensu Preston, 2011: $213 \&$ 223-228) between the upland plateau and the lowland plains for both humans and animals. Moreover, due to the karstic geology, there are numerous springs providing water in an otherwise river-less terrain. This and the fact the topography provides a protected environment means that it also concentrates plant and animal resources ${ }^{4}$. Also, the limestone geology also offered a potential chert source (Green, 1992; Waltham et al., 1997) for tools as well as the caves as a setting for shelter, domestic and ritual use. Therefore, the concentration of resources and transit route made the gorge a persistent place (sensu Barton et al., 1995; Preston, 2011; Schlanger, 1992) throughout prehistory.

The Karstic topography has an impact on how archaeologists and others discover the archaeology. For example, after the discovery of human occupation of caves throughout Europe (e.g. see in Rowley-Conwy, 2007; Trigger, 1989) by Victorian antiquarians and the growth of caving as a sport in the twentieth century has lead to many of the discoveries at Cheddar Gorge. It is, therefore, clear that the geography and geology of Cheddar Gorge was an important factor in the human occupation of the gorge and the discovery of archaeology in the caves. It is important to bear this in mind when considering the history of the archaeological work in the gorge.

\footnotetext{
${ }^{4}$ In fact, it was potentially a local 'refugium' during the glacial and early interglacial phases affording shelter for relict plant resources (e.g. see discussions in Birks and Willis, 2008; Holderegger and Thiel-Egenter, 2009; and especially: Médail and Diadema, 2009: 1335). However, more research is needed to substantiate this hypothesis.
} 


\section{ARCHAEOLOGICAL INVESTIGATIONS AT THE CHEDDAR CAVES}

The aim of this section is to assess the reliability of the sources relating to the archaeological resource of Cheddar Gorge. This is necessary to construct an accurate history of the interventions in the caves of Cheddar Gorge and to provide a realistic assessment of the archaeological record. The National Record of the Historic Environment (NRHE) lists 17 sites of archaeological interest in Cheddar Gorge (Figure 1C). In contrast to Balch's (1935) synthesis that presented the caves as two distinct groups depending on whether they were on the north or south side of the gorge, the authors of this paper examine each of the caves in alphabetical order. This approach allows for a comprehensive evaluation of each cave while at the same time providing an accessible resource for researchers. The assessment begins with Bone Hole.

\section{Bone Hole (ST 4803 5472)}

William Long carried out the earliest known investigation of Bone Hole (Figures 1C) which he described in a paper presented to British Association for the Advancement of Science in 1838. However, that it is not possible to establish with any certainty the veracity of Long's (1839) descriptions of this investigation because they are so vague. For instance, while Long (1839: 86) claims to have recovered human (including 12 human skulls) and animal remains (including bear, deer, ox, and horse) embedded in stalactite. It is not possible to verify Long's claims due to the vague report, and because the material has been missing for many years (Bryant, 2011: 142).

In contrast, a report by the Mendip Caving Group (MCG) (Cox, 1976) on their subsequent work at Bone Hole between August 1967 and 1976 provides slightly more information. This report details the activities of the MCG in Bone Hole, which mostly concerned the discovery of new extensions to the cave. However, the report also contains a brief account of the archaeological material encountered in an extension of the cave known as the West Rift. The West Rift was found to contain five human skulls resting on the appropriately named 'Skull Slope' (Cox, 1976: 25) and fragments of pottery embedded in the equally fitting epithet 'pottery corner' (Cox, 1976: 28). The description of the stratigraphic context is basic but supplementary plans and section drawings partially ameliorate this deficiency. Although, the most significant illustration is probably a reconstruction of a pot that appears to be an Early Bronze Age beaker. The Beaker provides the only dating evidence for the cave, although its present location is unknown. Although it seems probable that Bronze Age activity took place at Bone Hole, it is impossible to verify as the artefact's whereabouts is unknown. 
Accordingly, given the nature of the 'non-archaeological discovery' of the archaeology at Bone hole, the usefulness of the material as an indicator of activity is limited. This is because on the one hand the material Long recovered is unverifiable, and on the other it is not possible to ascertain the taphonomy of the archaeological layers from the West rift. Nonetheless, if the sources are to be trusted, it certainly suggests Bronze Age activity in the vicinity at the very least, just not necessarily in the cave per se.

\section{Chelm's Combe Rock Shelter (ST 4632 5445)}

The Somerset Archaeological and Natural History Society (SANHS), under the direction of Balch and the Reverend Palmer, undertook the first and only excavation of Chelm's Combe Rock Shelter (Figure 1C) between 1925 and 1926. Balch wrote a report alongside various specialists (1927) and published by the SANHS the following year.

According to the report, the excavation was conducted in arbitrary $\approx 30 \mathrm{~cm}$ (one foot) spits numbered from one to 22 in descending order (Jackson, 1927: 115). As a result, the archaeological material from different occupations was mixed up and assigned the same layer due to the slope of the deposits in the cave. However, during the excavation, the SANHS appear to have encountered a series of layers containing Neolithic, Bronze Age, and Iron Age artefacts, some of which were drawn and photographed for the report. The SANHS also claimed to have discovered a Pleistocene layer based on a comparison of the fauna with Aveline's Hole (Jackson, 1927: 121) as well as a putative Upper Palaeolithic bone whistle (Clay, 1927: 114).

The Wells Museum and the UBSS Museum now curate the finds from this fieldwork and subsequent analysis of them confirm the SANHS' reading of the deposits but reject other interpretations. For instance, the Early Neolithic occupation is confirmed by a radiocarbon measurement on a human long bone (Ambers and Bowman, 2003). Also, the existence of a Pleistocene fauna has been borne out by a series of radiocarbon measurements that fall within the Younger Dryas. However, the putative Upper Palaeolithic bone whistle has been dismissed by Jacobi (2004: 82) as the result of rodent gnawing. However, no evidence is offered to support this assertion. Thus, despite the inadequacies of the excavation, the archaeological material provides a valuable resource for researchers.

\section{Cooper's Hole (ST 4632 5402)}

Richard Frederick Parry (1933) undertook the initial excavation of Cooper's Hole (Figure 1C) during the winter months of 1931 to 1932, which he briefly described in a report in the 
Proceedings of the SANHS the following year. In the report a simple plan and section drawings that show four layers of sediment numbered from top to bottom near the cave entrance. Parry (ibid) described them as 'recent scree' and 'road-wash' (layer one) situated above a yellowish laminated clay (two), over 'unstratified scree' with a bluish clay matrix (three), atop homogenous reddish clay (four). According to Parry, layer two contained abundant charcoal that he believed accumulated during flooding. In contrast, Balch (1935: 76) speculated that the charcoal may have come from the Charterhouse lead works. However, the only unambiguously ancient archaeological material encountered was two sawn-off cuts of red deer antler and a few sherds of Early Iron Age pottery in layer three (ibid). This material is presumably in the collection at Cheddar, although the catalogue (Hendy, 2010) provides no information for establishing the provenance of artefacts from this particular intervention. Therefore, we must be circumspect when assessing the archaeological value of this resource.

The subsequent investigation of Cooper's Hole was undertaken by the MCG from March to December 1959 and was published in the MCG Journal the following year (Charnock, 2010). Like the MCG's exploration of Bone Hole, the excavation of Cooper's Hole was primarily concerned with finding new extensions to the cave. The MCG removed many tonnes of clay and rubble but recorded little stratigraphic information other than a basic plan. A report submitted to the MCG by Chris Reynolds (1962) partly corroborates the MCG interpretation of the stratigraphy.

Reynolds (1962: 60-61) visited the cave during the summer of 1961 to draw a section and encountered Parry's layers one to four and added to the characterisation. He identified four more strata and continued Parry's nomenclature by numbering them layers five to nine respectively. Reynolds (1962: 61) described this stratigraphy comprised a stalagmite floor (layer five), above angular stones embedded in a red clay matrix (six), over clayey sand (seven), atop fine sandy clay (eight), above alternate layers of gravel and sand (nine). Reynolds (ibid) reports that the animal remains (and presumably the pottery) derived from layers six and seven.

The artefacts and ecofacts the MGC recovered and Reynolds observed included the remains of horse, bird, rodent, and Fox, currently, the only dating available dating evidence for the cave was a few sherds of Iron Age pottery ( $\mathrm{ibid}$ ). This pottery was donated to the museum in Cheddar and is presumably represented by the ' $6.7 / 2$ ' accession entry that describes it as ' $a$ sherd of black pot decorated with groove inside lip and paired grooves with lattice pattern between ... outside from layer seven' (Hendy, 2010). Consequently, given there are questions related to 
its stratigraphy, exact location of recovery, and the ambiguous entry in the museum documentation, means that both the provenance of the pottery and the occupation in the cave may be suspect.

The final excavation of Cooper's Hole was carried out by the Time Team television programme from 22 to 24 April 1998 (Bellamy and Currant, 1998). They excavated in the car park in front of the cave entrance as well as inside of the cave, but this was cut short by rain that caused the water table to rise and inundate Cooper's Hole (Ashton, 1999). The only archaeological material recovered was a piece of bone with stone tool cut marks that could date to any time between the Palaeolithic and the Iron Age $(\text { ibid })^{5}$. In addition, the claims of cut marks cannot be verified directly because the location of the material is unknown ${ }^{6}$. The research value of this project is limited thus far because of the issues noted above and the fact that the excavation report (Bellamy and Currant, 1998) remains unpublished and inaccessible to the public thereby hindering any attempt to verify their claims.

\section{Flint Jack's Cave (ST 4632 5381)}

Flint Jack's Cave (Figure 1C), named after the infamous forger ${ }^{7}$, may invite the suspicion that any finds from there may be counterfeit. However, there are three reasons why this is not the case. First, unlike Pride Evan's Hole ${ }^{8}$, there is no evidence to show that Flint Jack visited the region (e.g. see in Richardson and Stamp, 1985; Sheppard, 1932). Secondly, the cave was eponymously entitled by Rowland Pavey in the 1890s as he wanted to develop the cave as a visitor attraction (Jacobi, 2004: 81). Thirdly, there is good archaeological evidence (see below) Late Palaeolithic, Bronze age and possibly Iron Age occupations in the cave (Jacobi, 2004: 81; Wells, 1958: 83). Thus, we need not doubt the archaeology on account of this toponym.

Around 1893, Pavey removed archaeological material from Flint Jack's Cave, but there is no published account of the excavation. However, some museums hold collections that may originate from Flint Jack's Cave. According to John Adlington Davies (1926: 264) a collection of 43 diagnostically Late Upper Palaeolithic stone tools (Accessions № 1903.33-50 and 1990.48.1-26) of purportedly uncertain attribution were loaned to the Weston-Super-Mare Museum by Montague Porch in 1903 and then purchased by them in 1920. Also, Davies (1926:

\footnotetext{
${ }^{5}$ It has never been subjected to radiocarbon dating to the authors knowledge.

${ }^{6}$ It is presumably in the care of Wessex Archaeology.

${ }^{7}$ Flint Jack's Edward Simpson (1815-1875) counterfeited many flint tools during the mid-nineteenth century (Jacobi, 2004: 81; Richardson and Stamp, 1985; Sheppard, 1932)

${ }^{8}$ Pride Evan's Hole is named after a former occupant.
} 
264) believed that Porch may have brought the collection from Pavey, but there is insufficient evidence in the record to substantiate this claim. However, there is another collection from Flint Jack's cave that has a more certain provenance.

This more reliable collection has 13 diagnostically Late Upper Palaeolithic stone tools (Accession № 1930.11-4.1-13) that were donated to the British Museum by Parry in 1930 . Although no excavation report was published, Davies (1929: 106) mentions a collection of stone tools from Flint Jack's Cave in the possession of Parry. Davies (ibid) suggests there appeared to be enough similarity in patination on the Flint to ascribe the collection to Flint Jack's Cave. However, the authors of this paper argue that patination would not be sufficient to establish a provenance because the diagenesis and the patination process of Flint are still not fully understood. Moreover, upon inspection, macroscopically, at least, the patina looks no different to that on lithics from other sites in the region. The evidence is, therefore, equivocal.

Similarly, another collection with a rather obscure history comprises parts of a human skullnamely the bones that make up the calvaria (Accession № M.16795-16796) - that were donated to the Natural History Museum by H. Eliot Walton in the spring of 1913. Walton claimed to have obtained the remains from Pavey and provided the museum with documentary evidence of their provenance (Oakley, 1958: 77). This provenance evidence comprised of a letter from Pavey stating that 'I have cleared out the old cave and have found a good number of flints and portions of bones and teeth' and a photograph showing human and animal bones in the cave entrance (Oakley, 1958: [cites Pavey 1913] 77). However, it is these author's opinion that while the attributed provenance is plausible or even likely, neither the manuscript nor the photograph, provide conclusive evidence of the provenance of the bones beyond doubt.

Despite the questions surrounding their provenance, subsequent archaeologists (e.g. Jacobi, 2004: 81) have accepted the Late Upper Palaeolithic attribution of the stone tools on typological grounds. However, a radiocarbon measurement on a human femur (Ambers and Bowman, 2003) yielded a Neolithic date, which suggests additional human activity at the cave. This bone was recovered by Roger Jacobi in 1990 during the removal of top soil which also happened to contain Bronze Age pottery and stone tools (Jacobi, 2004: 81). However, a full record of the excavation has not been published and the location of the material has not known, which makes it almost impossible to verify these claims.

Therefore, while it is impossible to be entirely sure that these collections derive from Flint Jack's Cave, the balance of evidence suggests that they are very likely to be. Moreover, even 
if it is not possible to pinpoint the archaeological to the cave, it remains more than probable that they originated from Cheddar Gorge. Thus, notwithstanding these caveats, the collection remains a significant archaeological resource for studies of human activity within the gorge during in the Palaeolithic and Neolithic.

\section{Great Oone's Hole (ST 4679 5393)}

Sometime around 1902 Montagu Porch removed archaeological material from Great Oone's Hole (Figure 1C), but he did not publish an account of his activities. Nevertheless, Davies (n.d.) believed that two stone tools in the Weston-Super-Mare Museum collection originated from Great Oone's Hole. Jacobi (Iles, 1990 [cites Jacobi 1989]; Jacobi, 1989) subsequently identified these lithics as accession numbers 1990.47.1 and 1990.47.2. Both these lithics were technologically classified by the authors of this paper as a non-formal retouched tool and a crested blade respectively (Davenport-Mackey and Preston, 2015). The crested blade is interesting because it has an en éperon platform suggestive of a Late Upper Palaeolithic date (see Barton, 1990). However, the steps by which Davies and Jacobi came to attribute the lithics to this cave is not mentioned. As a result, there remains some doubt about the attribution of the lithics to this cave.

The only documented excavation of Great Oone's Hole was in 1976 to 1977. An unpublished logbook held at the UBSS library provides the only record of the excavation. In the logbook, there is a basic description stratigraphy comprising 'a red limestone breakdown earth with many angular stones, above a yellow silt with many angular stones, over an archaeologically sterile marl' (Moody and Mullan, 2014: 121). The only archaeological material encountered derived from layer two. The finds are primarily animal remains (e.g. sheep/goat, rabbit, deer, horse, birds, rodents, insectivores, and amphibians). Although, the UBSS also discovered a flint blade fragment, a piece of glass, a cache of nuts, and charcoal from a hearth (Moody and Mullan, 2014: 121-122). At the moment it impossible to fully verify the accuracy of the logbook because the archaeological material, now missing, cannot be examined (Moody and Mullan, 2014: 122).

On 17 June 1979 the UBSS returned to Great Oone's Hole to remove the accumulated spoil of the previous two years of excavation and found two Roman coins in the process. These were believed lost, but recently Graham Mullan (2015) re-discovered them in the collection of the UBSS Museum alongside an illustration of the coins by made C.J. Hawkes in 1979. This suggests that the coins probably came from Great Oone's Hole. 
Clearly, the history of interventions in this cave, for the most part, are obscure. Archaeologists, therefore, need to be mindful of this when using this evidence. However, it would not be unreasonable to suggest that the material shows evidence of human activity in Cheddar Gorge at the very least.

\section{Gough's New Cave (ST 4670 5391)}

Gough's New Cave (Figure 1C) has undergone a succession of excavations and has yielded large amounts of Pleistocene material. The earliest known excavation of Gough's Cave was carried out by Richard Cox Gough between 1892 and 1898 who was primarily concerned with developing Gough's New Cave as a show cave and did not seek to record archaeological information (Irwin, 1986: 95). Indeed, the only record of the work is an article in the Wells Journal which states that Gough came across 'a large quantity of bones and teeth of extinct animals, besides a lot offlint knives and bone implements' (Irwin, 1986: 97; Jacobi, 1986: 102). Unfortunately, neither Irwin or Jacobi provide a bibliographic citation for this rather vague description. Thus, its validity cannot be ascertained with any certainty.

More sediment was removed by workmen excavating a drainage ditch in December 1903 who encountered the complete human skeleton that became known as Cheddar man (Baker, 1904; Davies, 1904, 1910, 1905; Gray, 1904; Jex-Blake, 1904). The earliest known account of the discovery of Cheddar man was produced by H.E. Davies (1904) who presented a paper at a meeting of the Geological Society of London on 13 April 1904. Davies' (1904: 342) report is perhaps the single most important because he managed to visit the cave while some of the bones were still lying in situ.

Davies' report provides a simple explanation of the stratigraphy in the cave entrance comprising a stalagmite floor, above a cave earth, over another stalagmite floor ${ }^{9}$ (Davies, 1904: 337-339). However, this description is supplemented by Davies' plan and section drawings of the fissure in which Cheddar man was discovered. Davies (1904: 345) claimed that Cheddar man and the flint blades, borers, and scrapers found in association date from the Late Upper Palaeolithic. He based this interpretation on comparisons of measurements of other cranial specimens and examples of stone tools published by Gabriel de Mortillet (Davies, 1904 [cites de Mortillet and de Mortillet, 1881]). Subsequent archaeologists have largely accepted the Late Upper Palaeolithic attribution of the stone tools. However, a series of radiocarbon

\footnotetext{
${ }^{9}$ Unlike in some of the other caves Davies (1904) did not number his strata.
} 
measurements on Cheddar $\operatorname{man}^{10}$ have produced an Early Mesolithic date (Gowlett et al., 1986b; Hedges et al., 1991a, 1989, 1987). This suggests that the stratigraphy may not be as discrete as Davies implies.

The first large scale archaeological excavation was undertaken by Parry during the winter months between November 1927 and January 1931. Parry $(1931,1929)$ published this work mainly in a truncated form in two reports. These reports detail the removal of the banks of sediment on each side of a path leading into the cave (Parry, 1929: 102). According to report the excavation proceeded in spits numbered from one to 25 in descending order and reached a depth of $4.27 \mathrm{~m}$ (14 feet) (ibid). This revealed a stratigraphy comprising of a reddish clayey cave earth with small angular limestones (spits one to five), above a similar layer with sand (six), over a breccia (seven-16), atop a gravel with waterworn pebbles and filling of sand and cave earth (17-23), above a clayey red loam and sand (24), over bedrock (25) (Parry, 1929: 105). During the excavation, Parry (1931: 47) encountered rich archaeological deposits in spits 10 to 16 .

For example, in spits 10 to 16 Parry (1931: 47) encountered 7000 diagnostically Late Upper Palaeolithic and Mesolithic stone tools. Some of which were illustrated for the report and 2202 survive in the collection at Cheddar (Hendy, 2010; Jacobi, 2004: 6). Also, the excavation recovered typologically Iron Age and Roman artefacts in the upper series of layers (Parry, 1929: 103), some of which were drawn and photographed for his report. Moreover, it appears that the most frequently encountered animal was the horse, the bones of which showed evidence of butchery in the form of stone tool cut marks (Parry, 1929: 104). The report also recorded numerous human skull fragments that were recovered during the excavation, a selection of which were illustrated in the report (Keith and Cooper, 1929). Clearly, Parry's excavations were extremely productive, though it is interesting that they were only published in truncated reports which somewhat limits the utility of the resource. Nonetheless, the sheer number of artefacts makes this a significant intervention.

Furthermore, the organic remains are important as subsequent radiocarbon measurements on them have produced a Late Upper Palaeolithic date for the occupation (Jacobi and Higham, 2011). However, as might be guessed from Parry's reports and his stratigraphic descriptions,

${ }^{10}$ The skeleton of Cheddar man is represented by skull 1.1/5 in the collection of the Museum at Cheddar. 
other radiocarbon measurements have shown that the stratigraphy is not as discrete as previously thought (Jacobi, 2004: 11).

Following this work, there were a series of poorly documented interventions that were not archaeological works per se. Thus, from 1934 to 1935 a cafe was built outside the entrance to Gough's Cave but nothing is known of the excavation (Tratman et al., 1972: 54) and the material was presumably found there by accident. The next was a series of non-archaeological interventions between 1948 and 1953 that were undertaken by Gough's Cave staff under the direction of Victor Painter. During this time, Desmond T Donovan (1955: 78) managed to record profiles of the excavated sections (1955: 78). In 1957, the path into the cave was lowered, and the iron gates at the entrance were removed, and Donovan managed to draw a section of the deposits, although they produced no archaeological material (Tratman et al., 1972: 54). In 1959, human remains were recovered during construction of a concrete path (Stringer, 1986: 150) and were preserved in the UBSS Museum and the collection at Cheddar. In 1968 the UBSS undertook a rescue excavation at the entrance of Gough's Cave while building work was in progress (Tratman et al., 1972: 49). They recovered human remains and pottery sherds which were donated to the collection at Cheddar although a calvaria and a humerus were loaned to the UBSS Museum (Tratman et al., 1972: 54). Clearly, there are difficulties with the material recovered, not least the paucity of documentation. However, we can be relatively sure they came from Gough's Cave and the approximate areas the 'trenches' were.

The latest excavation of Gough's Cave was carried out by the Natural History Museum (NHM) from 1986 to 1987 and represents a rare instance of a modern systematically controlled excavation in Cheddar Gorge. This investigation was briefly described in Antiquity by Currant and colleagues (1989) a few years later. Their report details the discovery of a pocket of sediment trapped behind a boulder composed of an upper fine gravel or underlying red silt, both with sharp limestone clasts, resting above a conglomerate (Currant et al., 1989: 132). This sediment was found to contain archaeological material, including human (cranial vault, including the calvaria, frontal bones, mandible and maxilla) and animal remains (including from collared lemming, narrow-skulled vole, and a medium-sized felid, lynx or leopard) (Currant et al., 1989: 133). The NHM also recovered a mammoth ivory sagaie and three diagnostically Late Upper Palaeolithic stone tools (ibid). The various cut-marks on the human bones are important in demonstrating that the deliberate de-fleshing of corpses took place in 
Gough's New Cave (Currant et al., 1989: 135-136). The location of the material is unknown ${ }^{11}$ but represents the most reliable evidence of human activity in Cheddar Gorge. It, therefore, represents an extremely useful research resource.

\section{Gough's Old Cave (ST 4678 5389)}

Between 1877 and 1889 Gough's Old Cave (Figure 1C) was a show-cave operated by Gough, who, despite making profound modifications to the interior to attract visitors, kept no record of any archaeological remains encountered (Tratman, 1960: 7-9). This material is presumably in the collection at Cheddar, although the catalogue provides no information for establishing the exact provenance of artefacts from this particular intervention.

The UBSS undertook the first and only systematic excavation of Gough's Old Cave during the winter months between 1954 and 1958. In 1960, a report by Edgar Kingsley Tratman (1960) was published in the Proceedings of the UBSS. This report gives a description of several layers of sediment numbered one to nine from top to bottom in the entrance of the cave (Tratman, 1960: 10-14). The report also includes a basic section drawing which comprises a welltrampled layer (one), earth with stones (two), the first hearth (three), brown earth and stones (four), the second hearth (five), soft tufaceous stalagmite (six), earth and stones (seven), looser material (eight), and silt (nine) (Tratman ibid). During the excavation, the UBSS encountered Roman and Late Iron Age artefacts associated with the first hearth, and Early Iron Age artefacts associated with the second hearth, some of which were illustrated in the report (ibid). The UBSS also stated they had discovered a glacial or post-glacial deposit composed of Auroch, lemming, reindeer, and beaver (Tratman, 1960: 16). Subsequent archaeologists have largely accepted this reading of the deposits. For instance, the interpretation of a Late Glacial occupation has since been confirmed by a radiocarbon measurement on a humanly modified horse phalange (Gowlett et al., 1986a). However, other radiocarbon measurements imply that the stratigraphy has been very badly disturbed (ibid). The Weston-Super-Mare Museum, the Taunton Museum, and the Oxford University Museum curate this material and there is also some in the collection at Cheddar. Collectively these collections represent a valuable research resource.

\footnotetext{
${ }^{11}$ It is presumably in the care of the NHM.
} 


\section{Long Hole (ST 4668 5387)}

The early history of interventions at Long Hole (Figure 1C) is both obscure and uncertain. For instance, Tratman (1955a) and Boon (1957) make reference to a hoard of Roman coins recovered from the talus slope, but they provide no information about the circumstances of the discovery. However, there is a hoard of Roman coins in the collection at Cheddar, although it is not associated with any provenance information, other than the name of the cave. It, therefore, remains to be seen if this hoard is the same one referred to by Tratman and Boon (ibid).

In contrast, a more careful investigation of Long Hole was undertaken by the UBSS in 1960 and a short note appeared in the Proceedings of the UBSS a few years later (Tratman, 1966). The report detailed the excavation of three trenches in the entrance of the cave that revealed very badly mixed deposits (Tratman ibid). However, the UBSS did encounter the remains of lemming, ox, lion, hare, reindeer, fallow deer, and black rat that were interpreted as having fallen through a hole in the roof (Tratman, 1966: 43). This is a very brief report and there are no radiocarbon measurements available which limit the potential of the resource.

More sediment was removed by subsequent excavation operations undertaken by the UBSS on 26 February 1977, although the results were never published as a formal document. However, Graham Mullan (2008: 99) reconstructed the stratigraphic contexts for Long Hole from Tratman's notebook. The strata described was an angular scree, above a trampled floor, over more angular scree, atop another compact layer. Mullan (ibid) was also able to compose a list of human and animal remains, pottery, and pins recovered by the UBSS. With the exception, a few pins (which have been destroyed-probably by Tratman) the finds are held in the UBSS Museum and represent a useful research resource. Thus, despite the lack of a detailed recorded contexts, the archaeological material represents a useful resource for researchers.

\section{Pigs Hole (ST 4770 5454)}

According to Balch (1947: 52) Pigs Hole (Figure 1C) was excavated by Parry in 1930 who found some Iron Age pottery sherds, but this claim cannot be substantiated because the material has gone missing. This, therefore, has limited research potential due to the reliance on the anecdotal information. 


\section{Pride Evan's Hole (ST 4687 5406)}

Pride Evan's Hole (Figure 1C) is another cave with a dubious history. ${ }^{12}$ A report published in the Proceedings of the UBSS by Tratman (1938) describes the circumstances surrounding the discovery of a hoard of 47 Roman coins from Pride Evan's Hole. Tratman (1938: 87) claims that the coins were discovered on 23 January 1926 when a group of explorers visited the cave and found a pocket of undisturbed sediment. This report contains an overview of the assessment of the 47 coins by H. Mattingly (Tratman, 1938: 88-89). However, the hoard's whereabouts is not known and therefore further corroboration is not possible.

\section{Saye's Hole (ST 4663 5389)}

The first and only investigation of Saye's Hole (Figure 1C) was undertaken by the University of Oxford in October 1986 and represents a rare instance of a modern controlled excavation in Cheddar Gorge. The excavation was published_in a detailed and extensive report in the Proceedings of the UBSS the following year (Barton et al., 1987). The report includes a detailed description of the stratigraphy and the 11 layers of sediment numbered from top to bottom and three archaeological horizons. These comprise a constructed floor (zero), loamy fine scree, archaeological unit (one), silty clay transition, clean sands-silts-clays, archaeological unit (two), clayey grit transition, stony cave earth, archaeological unit (three), basal clay silt, and bedrock (Collcutt et al., 1987: 107-110). During the excavation, the University of Oxford encountered a range of Late Iron Age artefacts associated with the hearths that comprise archaeological unit 2 and 3 (Barton et al., 1987: 111-112). These provide the only dating evidence for the cave although none was illustrated. Thus, on the one hand, the description of the features and context is helpful for research, but on the other hand, the lack of illustrations of the material, the whereabouts of which is unknown to the authors ${ }^{13}$ reduces the utility if this report. Nonetheless, it remains one of the most detailed reports of an excavation in Cheddar Gorge.

\section{Soldier's Hole (ST 4686 5400)}

The initial excavation of Soldier's Hole (Figure 1C) was undertaken by Balch (1928) between 1926 and 1927 and briefly described in a report in The Antiquaries Journal the following year. This report mentions a trench with an excavated depth of $61 \mathrm{~cm}(2 \mathrm{Ft}$.) but gives almost no description of the stratigraphic context (Balch, 1928: 207). However, the report contains a brief

\footnotetext{
${ }^{12}$ The cave was supposedly inhabited by Pride Evans and his family and it has been suggested that they may have contaminated the cave (Balch 1937: 54).

${ }^{13}$ It is presumably in the care of Oxford University.
} 
account of the archaeological material encountered in Soldier's Hole including Neolithic, Iron Age, and Roman artefacts from a layer of white tufa. Some of these artefacts were illustrated for the report and the material is currently held in the Wells Museum and the collection at Cheddar. Thus, despite the inadequacies of the excavation, the archaeological material provides a useful resource for researchers as the artefacts can be studied.

A subsequent excavation was undertaken by Parry (1931) from 1929 to 1930 and published by the SANHS a year later. Like some the sites already discussed in this paper, this excavation is somewhat unreliable due to the nature of the excavation. For instance, Parry (1931: 50) describes how the excavation was conducted in arbitrary $15.24 \mathrm{~cm}$ (6 inches) spits numbered from one to 21 in descending order (Parry, 1931: 50). However, the discontinuous layers of sediment necessitated a major revision of the excavation strategy. As a result, the excavation proceeded in 4 natural layers which conformed to the slope of the deposits and 21 working layers that were synonymous with the spits (Parry, 1931: 52). Parry describes a friable limey cave earth and leaf mould with stalagmite bosses (natural layer one, working layer one above a buff cave earth (natural layer two, working layer two to three), over a red marl with calcite crystals (natural layer three, working layer four to nine), atop a dark red marl with slightly rounded limestones (natural layer four, working layers 10 to 17), above the same material that had filled a fissure in the floor (working layer 18 to 21) (Parry, 1931: 52). Consequently, the stratigraphy is very difficult to interpret from the report and possibly unreliable.

Nevertheless, from a research perspective, the descriptions of the significant archaeological remains encountered are useful. For example, the report is of particular importance for establishing the presence of 13 typologically diagnostic Late Upper Palaeolithic lithics from in natural layer three-working layers four to nine and seven diagnostically Upper Palaeolithic leaf points from natural layer four-working layer 10 to 17 (Parry, 1931: 50-51). Subsequent archaeologists (inter alia Campbell, 1977; Jacobi, 2004) have largely accepted this reading of the deposits, although a series of radiocarbon measurements on unmodified animal bone (Gowlett et al., 1986b; Hedges et al., 1994, 1991b, 1989) suggests that the stratigraphy is not as discrete as previously thought. Therefore, while the somewhat ad-hoc excavation methods and recording techniques coupled with the radiocarbon measurement reduce the reliability of the cave as a research resource for reconstructing behaviour on a micro-scale, the lithics indicate a general Palaeolithic human presence in the vicinity of the cave. It remains, therefore, a relatively useful resource. 


\section{Sows Hole (ST4784 5455)}

Although no archaeological material has been recorded from Sows Hole (Figure 1C), the cave has often been confused with Pigs Hole where Parry supposedly encountered some Iron Age pottery (Balch, 1947: 52). As a result, Sows Hole has little archaeological potential unless work is undertaken there in future.

\section{Sun Hole (ST 4673 5408)}

The first excavation of Sun Hole (Figure 1C) was undertaken by the UBSS between 1926 and 1928 and was described by Henderson and Tratman (1928) in a report in the Proceedings of the UBSS the same year. Four strata are described in the report that is accompanied by plan and section drawings (Henderson and Tratman, 1928: 86). Henderson and Tratman describe the strata as humus with many stones, above dark earth and stones, over a hearth, atop a Late Pleistocene rubble. Neolithic, Bronze Age, Iron Age, and Roman artefacts were recovered from these strata. Some of these artefacts were drawn and photographed for the report. Unfortunately, the vast majority of this collection was destroyed during a bombing raid on Bristol in World War II. This means the researcher must rely on the report and thus, not all claims can be verified.

The following investigation of Sun Hole was also conducted by the UBSS between 1951 and 1953. A report published a few years later in the Proceedings of the UBSS details the excavation of the Late Pleistocene rubble accompanied by a basic plan and section drawing. This layer was excavated in $\approx 30 \mathrm{~cm}$ (one foot) spits and most of the archaeological material was recovered from the fifth and sixth spits (Tratman, 1955b: 68). This material includes typologically diagnostic Late Upper Palaeolithic and Mesolithic lithics, some of which were illustrated in the report. This material is conserved in the UBSS Museum and, therefore, is verifiable.

Indeed, subsequent archaeologists have largely accepted Tratman's (1955b) interpretation of the deposits and material culture as a Late Glacial occupation. For instance, typological analysis of the lithics by John Campbell (1977) and Roger Jacobi (2004) and technological analysis by the authors of this paper (Davenport-Mackey, In Prep.; Davenport-Mackey and Preston, In prep.) largely replicate Tratman's Late-Glacial interpretation. Furthermore, a series of radiocarbon measurements on the human and humanly modified bone (Jacobi and Higham, 2011) also support this interpretation. However, there has been some disagreement surrounding the stratigraphy. A case in point is John Campbell's (1977) excavation in the 
entrance of the cave in 1968. Based upon this Campbell proposed a new stratigraphic model for Sun Hole (Collcutt et al., 1981: 34) but Simon Collcutt (1981: 22) later rejected this as overly simplistic. Nonetheless, the quality of the documentation and the availability of the artefacts for further analysis means that this site represents a significant resource for future research.

\section{Sugar Loaf Slitter (ST 4683 5454)}

There appears to be few if any records of archaeological work undertaken at Sugar Loaf Slitter. There is, however, a statement by Balch (1947: 50-51) that suggests the Gough's found bones of lion, bear, hyena, and rhinoceros here (Figure 1C). However, this claim cannot be substantiated and is therefore of very limited archaeological research value.

\section{Totty Pot (ST 4825 5356)}

In some articles, Paula Gardiner $(2009 ; 2010)$ has reported that Totty Pot (Figure 1C) was initially excavated by the Wessex Cave Club (WCC) between 1960 and 1965. Although Gardiner (2010: 76) does not reveal the source of this information, it appears that the WCC were primarily concerned with the discovery of new extensions to the cave and the recovery of archaeological material was unexpected. The implications of this are that the artefacts were probably not recovered as carefully as might be in a modern professional archaeological intervention. However, work proceeded more carefully after 1963 and in this second phase, the WCC exposed various kinds of archaeological material, including Late Mesolithic stone tools and Bronze Age and Roman pottery, although no excavation report was ever published (ibid). The WCC also discovered human remains that were subsequently handed over to the police and destroyed (Gardiner et al., 2010: 77). However, a radiocarbon measurement on a surviving human humerus has revealed a Neolithic date (Ambers and Bowman, 2003), although the present location of the other material is unknown ${ }^{14}$. Thus given the lack of a published excavation report and in the absence of the material, this account is currently of limited research potential.

In contrast, Gardiner (2001) undertook a systematic excavation near the cave entrance in 1998. She recovered 25 typologically diagnostic Late Mesolithic stone tools, some of which have been illustrated in various reports (e.g. see in 2009; 2010). Also, a series of radiocarbon measurements on human remains from Totty Pot confirm Mesolithic and Neolithic activity

\footnotetext{
${ }^{14}$ It is presumably in the care of WCC.
} 
took place at the cave (Gardiner et al., 2010). However, given that the location of the material is unknown ${ }^{15}$ and that that the details of the excavation are part of Gardiner's (2001) unpublished Ph.D. thesis, it is difficult for the authors of this paper to evaluate both the circumstances surrounding the investigation and the interpretations derived from the material.

\section{White Spot Cave (ST 4739 5442)}

There does not seem to have been any archaeological interventions at White Spot Cave (Figure 1C). There is, however, an anecdote retold by Balch (1947: 51-52) that a boy discovered a pot here which crumbled on contact. However, this claim cannot be substantiated and is, therefore, this hearsay of very limited archaeological research value.

\section{CONCLUSION}

Having surveyed and evaluated the history of work in the gorge and its archaeological resource, it is possible for us to learn the lessons from those that went before us. The archaeological resource is non-renewable and without clear recording, documentation, and effective curration evidence is ultimately lost. Poor methods and inaccurate reporting means that it hinders subsequent research. However, it would be unfair to judge the work of the past by today's standards. Rather good historiography requires us to understand the work in its own context and especially the milleau of the day. Likewise, we have observed through evaluating the sources that it is unwise to simply repeat anecdotal information or indeed histories verbatim witout evaluating the sources provided. Any histories of archaeological work must also be sound as uncritical analyses serve to pervert the history of work, and promote unhelpful interpretations and thus the course of future research. Therefore, bringing this all together, while the excavation methods, recording techniques and reporting were variable, it is still possible with careful evaluation to glean useful information from surviving accounts of interventions at Cheddar Gorge. Thus, the legacy material and reports may be useful for future research.

Thus, to conclude, the aim of this paper has been to conduct a systematic review of archaeological studies and excavation reports in order to assess the claims of archaeological discoveries in Cheddar Gorge. Contrary to Balch's (1935: 106) of 'a hoary antiquity of unimagined remoteness' this study as revealed a concrete and accessible past. Although there

\footnotetext{
${ }^{15}$ It is presumably in the care of Bristol University.
} 
are problems associated with excavation methods and recording techniques it can confidently be stated that Cheddar Gorge was intermittently occupied from the Palaeolithic through to the Roman period during which time people engaged in manufacturing, domestic, ritual, and mortuary activities. It is hoped that this paper will provide a useful resource for researchers and provide stimulus for future study in Cheddar Gorge.

\section{ACKNOWLEDGEMENTS}

We would like to Graham Mullen and Linda Wilson for sharing, as yet, unpublished material. We thank Mary Saunders for her invaluable assistance and drafting the base map for Figure 1C for us. We thank Terry Hopkinson, Ollie Harris, and Nick Barton for advice on parts of our research. In addition, we thank and acknowledge University of Leicester, and Lithoscapes for funding. This paper was initially submitted to a journal but was withdrawn by the authors due to edits that would have changed the main arguments of the paper. Nonetheless, we thank the editors and reviewers of that journal for their comments and suggestions. Any errors our ours and ours alone.

\section{BIBLIOGRAPHY}

Ambers, J., Bowman, S., 2003. Radiocarbon Measurements from The British Museum: Datelist XXVI. Archaeometry 45, $531-540$.

Ashton, M., 1996. Cheddar Gorge, Somerset. Time Team. Chanel 4 Television.

Baker, E.E., 1904. Prehistoric man at Cheddar: programme of the excursion on Saturday, May 14th, 1904. Proceedings of the Somersetshire Archaeological and Natural History Society 1-4.

Balch, H.E., 1935. Mendip: Cheddar, Its Gorge and Caves. Clare Son \& Co, Bristol.

Balch, H.E., 1928. Excavations at Wookey Hole and other Mendip Caves, 1926-7. The Antiquaries Journal 8, $193-210$.

Balch, H.E., 1927. Excavations at Chelms Combe Cheddar. Proceedings of the Somersetshire Archaeological and Natural History Society 72, 93-123.

Barton, R.N.E., 1990. The En Éperon Technique in the British Late Upper Palaeolithic. Lithics 11, 31-33.

Barton, R.N.E., Berridge, P.J., Walker, M.J.C., Bevins, R.E., 1995. Persistent Places in the Mesolithic Landscape: An Example from the Black Mountain Uplands of South Wales. Proceedings of the Prehistoric Society 61, 181-116.

Barton, R.N..E., Brown, L., Collcutt, S.N., Laws, C., 1987. Saye's Hole, Cheddar, Somerset: A new Late Iron Age site. Proceedings of the University of Bristol Speleological Society 18, 105-115.

Bellamy, P., Currant, A., 1998. Cooper's Hole, Cheddar Gorge, Somerset: archaeological investigations by the Time Team. Unpublished Terrain Archaeology Report.

Birks, H.J.B., Willis, K.J., 2008. Alpines, trees, and refugia in Europe. Plant Ecology \& Diversity 1, 147-160.

Boon, G.C., 1957. Roman coins from Gough's Old Cave and The Slitter, Cheddar. Numismatic Chronicle 17, $231-237$.

Branigan, K., Dearne, M.J., 1991. Romano-British Usage of the Caves of Cheddar Gorge. Proceedings of the University of Bristol Speleological Society 19, 19-31.

Bryant, A., 2011. Iron Age Cave Use on Mendip: A Re-evaluation, in: The Archaeology of Mendip 500,000 Years of Continuity and Change. Oxbow, Oxford, pp. 139-158.

Buckhout, R., 1975. Eye Witness Testimony. Jurimetrics Journal 15, 171-187.

Campbell, J.B., 1977. The Upper Palaeolithic of Britain: a study of man and nature in the late Ice Age. Clarendon Press, Oxford.

Carver, M., 1996. On archaeological value. Antiquity 70, 45-56.

Charnock, R., 2010. Cooper's Hole. Mendip Caving Group. URL http://www.mendipcavinggroup.org.uk/sections/news/journal002.html\#coopers (accessed 12.20.15). 
Clay, R.C.C., 1927. Report on the Bone and Flint Implements. Proceedings of the Somersetshire Archaeological and Natural History Society 72, 113-115.

Clifford, B.R., Scott, J., 1978. Individual and situational factors in eyewitness testimony. Journal of Applied Psychology 63, $352-359$.

Collcutt, S.N., Currant, A.P., Hawkes, C.J., 1981. A further report on the excavations at Sun Hole, Cheddar. Proceedings of the University of Bristol Speleological Society 16, 21-38.

Conneller, C., 2007. Inhabiting New Landscapes: Settlement and Mobility in Britain After the Last Glacial Maximum. Oxford Journal of Archaeology 26, 215-237.

Cox, A.B., 1976. An interim report of the excavation work carried out at the Bone Hole, Cheddar Gorge. Mendip Caving Group Journal 6, 17-30.

Currant, A.P., Jacobi, R.M., Stringer, C., 1989. Excavations at Gough's Cave, Somerset 1986-7. Antiquity 63, 131-6.

Darvill, T., 1994. Value systems and the archaeological resource. International Journal of Heritage Studies 1, 52-64.

Davenport-Mackey, K., In Prep. Becoming Creswellian: Reconsidering Approaches to the Hunter-Gather Occupation of the Landscape During the Late Upper Palaeolithic of Britain (PhD Thesis). School of Archaeology and Ancient History, University of Leicester, Leicester.

Davenport-Mackey, K., Preston, P.R., 2015. A technological Analysis of the Lithic assemblage from Great Oones Hole.

Davenport-Mackey, K., Preston, P.R., In prep. The Sunnyside of Late-Glacial Life: preliminary findings from the analysis of the lithic assemblage from Sun Hole, Cheddar Gorge, UK. Proceedings of the University of Bristol Speleological Society (Invited article-pre-submission).

Davies, H.., 1904. The Discovery of Human Remains under the Stalagmite Floor on Gough's Cavern, Cheddar. Quarterly Journal of the Geological Society 60, 335-348.

Davies, H.N., 1910. Gough's Cavern, Cheddar. Proceedings of the Somersetshire Archaeological and Natural History Society $55,79-81$.

Davies, H.N., 1905. The discovery of human remains under stalagmite in Gough's Cave, Cheddar, Somerset. Report of the British Association for the Advancement of Science 569-570.

Davies, J., 1926. Notes on Upper Palaeolithic implements from some Mendip Caves. Proceedings of the University of Bristol Speleological Society 2, 261-273.

Davies, J.A., 1929. Flint implements found in Gough's Cave, 1927-28. Proceedings of the Somerset Archaeological and Natural History Society 74, 106-111.

Davies, J.A., n.d. Archaeological Notes.

de Mortillet, L.L.G., de Mortillet, A., 1881. Musée Préhistorique. Paris.

Donovan, D.T., 1955. The Pleistocene deposits at Gough's Cave, Cheddar, including an account of recent excavations. Proceedings of the University of Bristol Speleological Society 7, 76-104.

Fling, F.M., 1899. Outline of Historical Method. J H Miller, Lincoln.

Fling, F.M., Theodore, L., 1920. The writing of history; an introduction to historical method. Yale University Press, New Haven.

Gardiner, P.J., 2009. South-western regional identities: Birdcombe, Totty Pot and Hawkcombe Head, in: McCartan, S.B., Schulting, R., Warren, G., Woodman, P. (Eds.), Mesolithic Horizons. Oxbow Books, Oxford and Oakville, pp. 485493.

Gardiner, P.J., 2001. The Mesolithic-Neolithic transition in South West England. University of Bristol. Unpublished PhD Thesis.

Gardiner, P.J., Hawkes, C.J., Murray, E., Schulting, R.J., 2010. The Mesolithic-Neolithic human bone assemblage from Totty Pot. Proceedings of the University of Bristol Speleological Society 25, 75-95.

Glassow, M.A., 1977. Issues in Evaluating the Significance of Archaeological Resources. American Antiquity 42, 413-420.

Gowlett, J.A.J., Hall, E.T., Hedges, R.E.M., Perry, C.., 1986a. Radiocarbon Dates from the Oxford AMS System: Archaeometry Datelist 3. Archaeometry 28, 116-125.

Gowlett, J.A.J., Hedges, R.E.M., Law, L.A., Perry, C.., 1986b. Radiocarbon Dates from the Oxford AMS System: Archaeometry Datelist 4. Archaeometry 28, 206-21.

Gray, H., 1904. Notes on the skeleton and flints found in Gough's Cave. Notes and Queries for Somerset and Dorset 9, 2-5.

Green, G.W., 1992. Bristol and Gloucester region, 3rd ed, British Regional Geology. Her Majesty’s Stationary Office, London. 
Green, G.W., Welch, F.B.A., 1965. Geology of the Country around Wells and Cheddar, Memoirs of the Geological Survey of Great Britain. Her Majesty's Stationary Office, London.

Hedges, R.E.M., Housley, R.A., Bronk Ramsay, C., Van Klinken, G.J., 1991a. Radiocarbon Dates From The Oxford AMS System: Archaeometry Datelist 13. Archaeometry 33, 279-296.

Hedges, R.E.M., Housley, R.A., Bronk Ramsey, C., Van Klinken, G.J., 1994. Radiocarbon Dates from the Oxford AMS System: Archaeometry Datelist 18. Archaeometry 36, 337-374.

Hedges, R.E.M., Housley, R.A., Bronk Ramsey, C., Van Klinken, G.J., 1991b. Radiocarbon Dates From The Oxford AMS System: Archaeometry Datelist 12. Archaeometry 33, 121-134.

Hedges, R.E.M., Housley, R.A., Law, I.A., Perry, C., Gowlett, J.A.J., 1987. Radiocarbon Dates From The Oxford AMS System: Archaeometry Datelist 6. Archaeometry 29, 289-306.

Hedges, R.E.M., Housley, R.A., Law, L.A., Bronk, C., 1989. Radiocarbon Dates from the Oxford AMS System: Archaeometry Datelist 9. Archaeometry 31, 207-234.

Henderson, G.T.D., Tratman, E.K., 1928. First Report on the excavations at Sun Hole, Cheddar. Proceedings of the University of Bristol Speleological Society 5, 87-89.

Hendy, P.G., 2010. Cheddar Archaeology Catalogue and Misc Items.

Holderegger, R., Thiel-Egenter, C., 2009. A discussion of different types of glacial refugia used in mountain biogeography and phylogeography. Journal of Biogeography 36, 476-480.

Hunter, J., Ralston, I., 2006. Archaeological resource management in the UK: an introduction. Alan Sutton, Stroud.

Iles, R., 1990. Archaeology Gallery Permanent Display - The Ice Age. Unpublished Manuscript, Taunton Heritage Trust, Taunton.

Irwin, D.. J., 1986. The exploration of Gough's Cave and its development as a show cave. Proceedings of the University of Bristol Speleological Society 17, 95-101.

Jackson, J.W., 1927. The Vertebrate and Molluscan Fauna. Proceedings of the Somersetshire Archaeological and Natural History Society 72, 115-123.

Jacobi, R., Higham, T., 2011. The Later Upper Palaeolithic Recolonisation of Britain: New Results from AMS Radiocarbon Dating, in: Ashton, N., Lewis, S.G., Stringer, C. (Eds.), The Ancient Human Occupation of Britain, Developments in Quaternary Science. Elsevier, Amsterdam; Oxford, pp. 223-248.

Jacobi, R.M., 2004. The Late Upper Palaeolithic Lithic Collection from Gough's Cave, Cheddar, Somerset and Human Use of the cave. Proceedings of the Prehistoric Society 1-92.

Jacobi, R.M., 1989. From The Cheddar Caves.

Jacobi, R.M., 1986. The History and Literature of Pleistocene Discoveries at Gough's Cave, Cheddar, Somerset. Proceedings of the University of Bristol Speleological Society 17, 102-115.

Jex-Blake, T.W., 1904. Prehistoric man at Cheddar. Notes and Queries for Somerset and Dorset 9, 1-2.

Keith, A., Cooper, N.C., 1929. Report on the human remains from Gough's Cave, Cheddar. Proceedings of the Somersetshire Archaeological and Natural History Society 74, 118-121.

Lewis, J., 2005. Monuments, Ritual and Regionality: The Neolithic of Northern Somerset, British Archaeological Reports. British Archaeological Reports, Oxford.

Loftus, E.F., 1979. Eyewitness Testimony. Harvard University Press, Cambridge.

Long, W., 1839. Description of a cave at Cheddar, in which human as well as animal bones have been lately found. British Association for the Advancement of Science Reports 7, 85-86.

Médail, F., Diadema, K., 2009. Glacial refugia influence plant diversity patterns in the Mediterranean Basin. Journal of Biogeography 36, 1333-1345x

Moody, A.A.D., Mullan, J.G., 2014. An account and survey of Great Oone's Hole, Cheddar Gorge, Somerset. Proceedings of the University of Bristol Speleological Society 26, 117-130.

Mullan, G., 2015. Archaeological Note: Two Roman Coins from Great Oone's Hole Cheddar Gorge. Proceedings of the University of Bristol Speleological Society 26, 271-274.

Mullan, G.J., 2008. Excavations in Long Hole, Cheddar, February 1977. Proceedings of the University of Bristol Speleological Society 24, 97-100.

Oakley, K.P., 1958. The Antiquity of the Skulls Reputed to be from Flint Jack's Cave, Cheddar, Somerset. Proceedings of the University of Bristol Speleological Society 8, 77-82. 
Parry, R.F., 1933. Excavations at Cooper's Hole. Proceedings of the Somerset Archaeological and Natural History Society 43, 52 .

Parry, R.F., 1931. Excavations at Cheddar. Proceedings of the Somerset Archaeological and Natural History Society 76, 4662.

Parry, R.F., 1929. Excavation at the Caves, Cheddar. Proceedings of the Somerset Archaeological and Natural History Society $74,102-121$.

Preston, P.R., 2011. Lithics to Landscapes: Hunter Gatherer tool use, resource exploitation and mobility during the Mesolithic of the Central Pennines, England (Unpublished D.Phil. Thesis). School of Archaeology, University of Oxford, Oxford.

Reynolds, C., 1962. The deposits of Coopers Hole. Mendip Caving Group Journal 3, 60-61.

Richardson, M., Stamp, T., 1985. Flint Jack. Caedmon of Whitby Publishers, Whitby.

Rowley-Conwy, P., 2007. From genesis to prehistory: the archaeological three age system and its contested reception in Denmark, Britain, and Ireland. Oxford University Press, Oxford; New York.

Schiffer, M.B., 1987. Formation Processes of the Archaeological Record. University of New Mexico Press, Albuquerque.

Schlanger, S.H., 1992. Recognising Persistent Places in Anasazi Settlement Systems, in: Rossignol, J., Wandsnider, L. (Eds.), Space, Time, and Archaeological Landscapes, Interdisciplinary Contributions to Archaeology. Plenum, London, pp. 91-112.

Sheppard T., 1932. Fact And Fiction In Geology. Proceedings of the Yorkshire Geological and Polytechnic Society 22, 7392.

Smith, C., 1992. Late Stone Age Hunters of the British Isles. Routledge, London.

Stringer, C.B., 1986. The Hominid Remains From Gough's Cave. Proceedings of the University of Bristol Speleological Society 17, 145-152.

Tilley, C.Y., 1994. A Phenomenology of Landscape: Places, Paths and Monuments. Berg, Oxford.

Tratman, E.K., 1966. Archaeological Notes - Trial investigations at and the Pleistocene fauna from the Long Hole, Cheddar. Proceedings of the University of Bristol Speleological Society 11, 42-43.

Tratman, E.K., 1960. Gough's Old Cave, Cheddar, Somerset. Proceedings of the University of Bristol Speleological Society $9,7-21$.

Tratman, E.K., 1955a. Notes on some human jaws and teeth from "The Slitter", Cheddar. Proceedings of the University of Bristol Speleological Society 7, 110-114.

Tratman, E.K., 1955b. Second Report on the excavations at Sun Hole, Cheddar: The Pleistocene levels. Proceedings of the University of Bristol Speleological Society 7, 61-72.

Tratman, E.K., 1938. Archaeological Notes - A hoard of Roman coins from Pride Evans' Hole, Cheddar Gorge. Proceedings of the University of Bristol Speleological Society 5, 87-89.

Tratman, E.K., Donovan, D.T., Musgrave, 1972. Gough's Cave, Cheddar, Somerset. Rescue dig November 1968. Sections exposed in 1957. Proceedings of the University of Bristol Speleological Society 13, 49-60.

Trigger, B.G., 1989. A History of Archaeological Thought. Cambridge University Press, Cambridge.

Vann, R.T., 2015. Historiography. Merriam Webster. URL http://www.merriam-webster.com/dictionary/historiography (accessed 12.16.15).

Waltham, A.C., Simms, M.J., Farrant, A.R., Goldie, H.S., 1997. Karst and Caves of Great Britain, Geological Conservation Review Series. Chapman and Hall, London.

Wells, G.L., Olson, E.A., 2003. Eyewitness Testimony. Annual Review of Psychology 54, 277-295.

Wells, L.H., 1958. Human remains from Flint Jack's Cave, Cheddar, Somerset. Proceedings of the University of Bristol Speleological Society 8, 83-88.

Willems, W.J.H., 2008. Archaeological resource management and preservation. Geoarchaeological and Bioarchaeological Studies 10, 283-289. 